\title{
АЗОПРОИЗВОДНЫЕ ПИРИДОКСИНА - ПЕРСПЕКТИВНЫЙ КЛАСС ИНГИБИТОРОВ КОНЕЧНЫХ ПРОДУКТОВ ГЛИКИЛИРОВАНИЯ
}

\section{А.Д. Стрельник', Ю.Г. Штырлин ${ }^{1}$, А.А. Спасов², Р.А. Литвинов ${ }^{2}$}

${ }^{1}$ Научно-образовательный центр фармацевтики, Казанский (Приволжский) федеральный университет, 420008, Россия, г. Казань, ул. Кремлевская, 18.

${ }^{2}$ Кафедра фармакологии и биоинформатики, Волгоградский государственный медицинский университет, 400131, Россия, г. Волгоград, пл. Павших борцов, 1.

DOI: 10.19163/MedChemRussia2021-2021-488

E-mail:Alexei.Strelnik@kpfu.ru

Конечные продукты гликирования (КПГ) - большая группа разнообразных органических соединений, образующихся в результате взаимодействия белков с карбонильными соединениями. Внутри-и внеклеточное накопление КПГ считается важным фактором патогенеза осложнений сахарного диабета, атеросклероза, ревматоидного артрита, нейродегенеративных заболеваний.

В настоящей работе синтезирован широкий ряд производных пиридоксина и исследована их антигликирующая активность:<smiles>[R2]Cc1c(N)nc(C)c(O)c1CO[R2]</smiles>

Азопроизводные пиридоксина I со свободной ароматической гидроксильной группой проявляют высокую ингибирующую активность $\left(\mathrm{IC}_{50}\right.$ варьируется в пределах (20-110) $\mu \mathrm{M})$, значительно превышающую активность препарата сравнения аминогуанидина (IC $765 \mu \mathrm{M})$. Введение в структуру молекулы I заместителей $\mathrm{R}^{3}$ приводит к резкому (до 20 раз) снижению ингибирующей активности, а восстановление азогруппы до аминопроизводных II - к полной потере антигликирующих свойств.

Таким образом, производные пиридоксина, содержащие азогруппу в шестом положении пиридоксина, являются перспективным скаффолдом для поиска новых ингибиторов образования КПГ. 